\title{
More Uncertainty After Daimler AG v. Bauman: A Response to Professors Cornett and Hoffheimer
}

\author{
DeBorah J. ChALLENER*
}

In response to Judy M. Cornett \& Michael H. Hoffheimer, Good-Bye Significant Contacts: General Personal Jurisdiction After Daimler AG v. Bauman, 76 OHIO ST. L.J. 101 (2015).

\section{TABLE OF CONTENTS}

I. INTRODUCTION

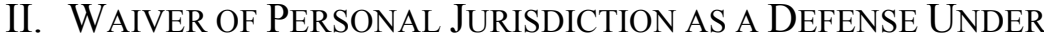

RULE 12 68

III. WAIVER UNDER GOODYEAR AND DAIMLER: THE CASE LAW............... 70

IV. WAIVER UNDER GOODYEAR AND DAIMLER: AN ANALYSIS ................. 73

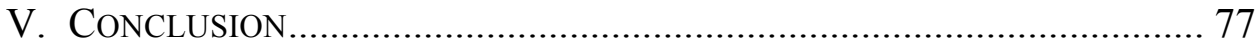

\section{INTRODUCTION}

In Good-Bye Significant Contacts: General Personal Jurisdiction After Daimler AG v. Bauman, ${ }^{1}$ Professors Judy M. Cornett and Michael H. Hoffheimer identify a number of legal issues that will become the focus of litigation after Daimler. ${ }^{2}$ This Response identifies an additional, perhaps surprising issue that is currently being litigated in the wake of Daimler $A G v$. Bauman. In the lower federal courts, defendants who have litigated cases on the merits without raising lack of personal jurisdiction as a defense are filing motions to dismiss and arguing that they are not subject to general jurisdiction in the forum under Daimler's "at home" standard. The question is whether these defendants have waived their jurisdictional defense under Federal Rule of Civil Procedure 12 because it was "available" to them in 2011 after Goodyear Dunlop Tires

* Professor of Law, Mississippi College School of Law. B.A., Oberlin College; M.P.P., Vanderbilt University; J.D., University of Tennessee College of Law.

${ }^{1}$ Judy M. Cornett \& Michael H. Hoffheimer, Good-Bye Significant Contacts: General Personal Jurisdiction After Daimler AG v. Bauman, 76 OHIO ST. L.J. 101 (2015).

${ }^{2}$ See id. at 136-55 (stating that the following issues will become the focus of litigation after Daimler: whether appointment of an agent for purposes of service of process can constitute effective consent to either specific or general jurisdiction, the scope of Justice Ginsburg's opinion, the proper application of Daimler's comparative approach, the role of corporate expectations in general jurisdiction, the identification of "place of incorporation" and "principal place of business," and the "exceptional circumstances" that will render a corporation "essentially at home" somewhere other than its place of incorporation and principal place of business). 
Operations, S.A. v. Brown ${ }^{3}$ was decided. ${ }^{4}$ This Response explains the doctrine of waiver under Rule 12 and examines three cases that have addressed waiver under Goodyear and Daimler. ${ }^{5}$ This Response then asserts that defendants who failed to argue that they were not "at home" in the forum after Goodyear waived their jurisdictional defense and should not be permitted to raise it under Daimler.

\section{Waiver of Personal Jurisdiction as a Defense Under Rule 12}

Under Federal Rule of Civil Procedure 12(h)(1), lack of personal jurisdiction is a "threshold defense" that is "waived if [it is] not included in a preliminary motion under Rule 12 as required by Rule $12(\mathrm{~g})$ or, if no such motion is made, [is] not included in the responsive pleading or an amendment as of right to that pleading under Rule 15(a)."'6 This Rule is not absolute, however. If the defendant omits a personal jurisdiction defense from a Rule 12(b) motion to dismiss or a responsive pleading because it was unavailable at the time, then he does not waive it. ${ }^{7}$ He can assert the new defense in a second Rule 12(b) motion or in his answer, ${ }^{8}$ but he must raise it "as soon as [its] cognizability is made apparent." 9 Although the case law in this area is sparse, the courts that have addressed the issue have concluded that a defense is unavailable under Rule 12(g)(2) "if its

${ }^{3}$ Goodyear Dunlop Tires Operations, S.A. v. Brown, 131 S. Ct. 2846 (2011).

4 This issue first came to my attention in an email sent by Professor Kevin M. Clermont to the Civil Procedure Listserv on Thursday, Oct. 2, 2014. The discussion on the Listserv prompted me to write this Response on the topic of waiver and pointed me towards several cases that are cited herein.

5 The three cases are (1) Gilmore v. Palestinian Interim Self-Government Authority, 8 F. Supp. 3d 9 (D.D.C. 2014), (2) American. Fidelity Assurance Co. v. Bank of New York Mellon, No. CIV-11-1284-D, 2014 WL 4471606 (W.D. Okla. Sept. 10, 2014), and (3) Gucci America, Inc. v. Weixing Li, 768 F.3d 122 (2d Cir. 2014).

6 5C Charles A. Wright \& Arthur R. Miller, Federal Practice and Procedure $\S 1391$, at 498 (2004) (citing FED. R. CIV. P. 12(b)(2), (g), (h)(1)).

${ }^{7}$ FED. R. CIV. P. 12(g)(2) ("Except as provided in Rule 12(h)(2) or (3), a party that makes a motion under this rule must not make another motion under this rule raising a defense ... that was available to the party but omitted from its earlier motion.") (emphasis added); FED. R. CIV. P. 12(h)(1)(A) (stating that a party waives the defense of lack of personal jurisdiction by "omitting it from a motion in the circumstances described in Rule 12(g)(2)"); see also WRIGHT \& MILLER, supra note $6, \S 1388$, at 491 ("A significant qualification on the application of Federal Rule $12(\mathrm{~g})$ is that a party is only required to consolidate Rule 12 defenses and objections that are "then available to the party."'); Glater v. Eli Lilly \& Co., 712 F.2d 735, 738 (1st Cir. 1983) (stating that the "language of Rule 12(g) logically also applies to Rule 12(h) with the result that under that subsection defendants do not waive the defense of personal jurisdiction if it was not available at the time they made their first defensive move").

${ }^{8}$ WRIGHT \& MiLleR, supra note $6, \S 1388$, at $491-92$ (stating that a party can file a second motion to dismiss "based on a defense that he or she did not have reasonable notice of at the time that party first filed a motion to dismiss or on a defense that became available only after a motion had been made under Rule 12 " or "assert the newly revealed defense ... in the responsive pleading").

${ }^{9}$ Holzsager v. Valley Hosp., 646 F.2d 792, 796 (2d Cir. 1981). 
legal basis did not exist at the time of the answer or pre-answer motion." 10 In other words, a defendant does not waive a threshold defense where "for all practical purposes" binding precedent makes it "impossible" for the defendant to raise it in his first response to the complaint. ${ }^{11}$

In Holzsager v. Valley Hospital, an oft-cited waiver case, the Second Circuit found that the defendant did not waive its personal jurisdiction defense because the defense became available only after the U.S. Supreme Court overruled controlling Second Circuit authority. ${ }^{12}$ In Holzsager, the plaintiff sued the defendant hospital in 1976 and established jurisdiction over it by attaching an insurance policy issued to the defendant by a New York insurance company. ${ }^{13} \mathrm{At}$ the time, Seider v. Roth, a decision from the Court of Appeals of New York, authorized "the exercise of personal jurisdiction through quasi-in-rem attachment of insurance policies issued by resident insurers." 14 Despite criticism of Seidertype jurisdiction and Supreme Court precedent that called its constitutionality into question, ${ }^{15}$ the Second Circuit reaffirmed Seider in 1978 in O'Connor v. Lee-Hy Paving Corp. ${ }^{16}$ Then, in Rush v. Savchuck, "the Supreme Court declared Seider-type attachments unconstitutional."17

Shortly thereafter the defendant in Holzsager moved to dismiss for lack of personal jurisdiction, and the plaintiff responded that the defendant had waived its jurisdictional defense. ${ }^{18}$ The Second Circuit first held that the defendant did, in fact, timely assert a personal jurisdiction defense that was broad enough to include the argument that jurisdiction under Seider was unconstitutional. ${ }^{19}$ Nevertheless, the court concluded that even if the defendant had not previously raised its personal jurisdiction defense, it would not have waived the defense under Rules 12(g) and (h). The court reasoned that the legal basis for the defense did not exist until the Supreme Court overruled O'Connor in Rush, and a right

\footnotetext{
${ }^{10}$ Chatman-Bey v. Thornburgh, 864 F.2d 804, 813 n.9 (D.C. Cir. 1988) (citing Holzsager, 646 F.2d at 796; Glater, 712 F.2d at 738-39).

${ }^{11}$ See id.; Holzsager, 646 F.2d at 793-96; see also Hawknet, Ltd. v. Overseas Shipping Agencies, 590 F.3d 87, 91-92 (2d Cir. 2009). In the context of a Rule 60(b) motion for relief from a judgment, the First Circuit has similarly held that it "will excuse a party for failing to raise a defense only when the defense, if timely asserted, would have been futile under binding precedent." Bennett v. City of Holyoke, 362 F.3d 1, 7 (1st Cir. 2004). Generally, it is "futile" to raise a defense "only if (i) at the time of the procedural default, a prior authoritative decision indicated that the defense was unavailable, and (ii) the defense became available thereafter by way of supervening authority (say, an overruling of the prior decision or a legislative clarification)." Id.

12 Holzsager, 646 F.2d at 796.

${ }^{13}$ Id. at 794 .

${ }^{14}$ Id. (citing Seider v. Roth, 216 N.E.2d 312 (N.Y. 1966)).

${ }^{15}$ Id. at 795 (citing Shaffer v. Heitner, 433 U.S. 186 (1977)).

${ }^{16}$ Id. (citing O'Connor v. Lee-Hy Paving Corp., 579 F.2d 194 (2d Cir.), cert. denied, 439 U.S. 1034 (1978)).

${ }^{17}$ Id. (citing Rush v. Savchuk, 444 U.S. 320 (1980)).

18 See Holzsager, 646 F.2d at 795.

${ }^{19}$ Id. at 795-96.
} 
that is unknown cannot be waived. ${ }^{20}$ According to the Second Circuit, "[t]he clairvoyance demanded by [the] plaintiff ... of the [defendant was] inconsistent with the doctrine of waiver." 21

Similarly, in Hawknet, Ltd. v. Overseas Shipping Agencies, a maritime attachment lawsuit, the Second Circuit said that "the doctrine of waiver demands conscientiousness, not clairvoyance, from parties." 22 In Hawknet, the plaintiff argued that the defendant could not raise its personal jurisdiction defense on appeal because it had failed to raise it in the district court. ${ }^{23}$ The court agreed with the plaintiff's argument generally, but held that waiver was inapplicable on the facts of the case because controlling Second Circuit precedent had prevented the defendant from raising its jurisdictional defense in the district court. ${ }^{24}$ It was not until the Second Circuit overruled that precedent while the Hawknet appeal was pending that the defendant had "a new objection to the District Court's jurisdiction over it." 25 In these circumstances, the appellate court concluded that the defendant did not waive its personal jurisdiction defense by raising it for the first time on appeal. ${ }^{26}$

\section{WAIVER UNDER GOODYEAR AND DAIMLER: THE CASE LAW}

Currently, the lower federal courts are wrestling with the question of whether Daimler $A G$ v. Bauman provides defendants with a jurisdictional defense that was unavailable before Daimler was decided on January 14, 2014, or whether that defense was waived by the defendants' failure to quickly assert it after the Supreme Court decided Goodyear Dunlop Tires Operations, SA v. Brown in 2011. In these cases, the initial complaint was filed long before Daimler was decided, but the defendants did not raise personal jurisdiction as a defense. In particular, they did not argue that general personal jurisdiction was lacking because they were not "at home" in the forum under Goodyear. Then, shortly after the decision in Daimler, the defendants moved to dismiss for lack of personal jurisdiction on the ground that Daimler had changed the law of general personal jurisdiction and under Daimler they were not "at home" in the forum. The plaintiffs responded that the defendants had waived their defense under Rule $12(\mathrm{~g})(2)$ by failing to timely assert it.

In Gilmore v. Palestinian Interim Self-Government Authority, for example, the plaintiffs filed a lawsuit on April 18, 2001, against the Palestinian Interim Self-Government Authority (PA), the Palestine Liberation Organization (PLO) and eleven individual defendants in the U.S. District Court for the District of

${ }^{20}$ See id. at 796 (citing Curtis Publ'g Co. v. Butts, 388 U.S. 130, 143, 145 (1967)).

${ }^{21} I d$.

${ }^{22}$ Hawknet, Ltd. v. Overseas Shipping Agencies, 590 F.3d 87, 92 (2d Cir. 2009).

${ }^{23}$ Id. at 91 \& n. 8 (quoting FED. R. CIV. P. 12(h)(1) for the proposition "that a party can waive its right to challenge the district court's personal jurisdiction over it").

${ }^{24}$ See id. at 91-92.

${ }^{25} \mathrm{Id}$. at 92 .

${ }^{26} I d$. 
Columbia. ${ }^{27}$ The PA and PLO filed a motion to dismiss for lack of subject matter jurisdiction and failure to state a claim, which the district court denied in 2006. ${ }^{28}$ They did not formally raise lack of personal jurisdiction as a defense until February 10, 2014, when they filed a motion for judgment on the pleadings for lack of personal jurisdiction ${ }^{29}$ and argued that under Daimler "their contacts with the District of Columbia [did] not render them 'at home" "there. ${ }^{30}$

Similarly, in American Fidelity Assurance Co. v. Bank of New York Mellon, the plaintiff filed suit on November 1, 2011, in the U.S. District Court for the Western District of Oklahoma. ${ }^{31}$ The defendant moved to dismiss for failure to state a claim in response to both the initial and second amended complaints but did not raise lack of personal jurisdiction as a defense in either motion. ${ }^{32}$ The court denied the defendants' second 12(b)(6) motion on December 26, 2013, and the defendant filed an answer on January $10,2014 .{ }^{33}$ The defendant then moved to dismiss for lack of personal jurisdiction on March 3, 2014, and argued that general jurisdiction was lacking in light of Daimler. ${ }^{34}$ Like the defendants in Gilmore, the defendant in American Fidelity argued that Daimler changed the law and created a new legal basis for challenging general personal jurisdiction. ${ }^{35}$ More specifically, the defendant in American Fidelity argued that it was subject to general jurisdiction in Oklahoma before Daimler because it had continuous and systematic contacts with Oklahoma and controlling Tenth Circuit authority prevented it from raising general jurisdiction as a defense until after Daimler was decided. ${ }^{36}$ The defendant further argued that it was not subject to general jurisdiction in Oklahoma after Daimler because it was neither incorporated nor had its principal place of business there. ${ }^{37}$

In both Gilmore and American Fidelity, the district courts held that the defendants had waived their jurisdictional defense by failing to assert it promptly after Goodyear. ${ }^{38}$ Both courts reasoned first and most significantly that the defense of lack of general personal jurisdiction was available to the defendants after Goodyear because Goodyear, not Daimler, announced the new "at home" rule and the Daimler Court merely applied it. ${ }^{39}$ Second, both courts found,

${ }^{27}$ Gilmore v. Palestinian Interim Self-Gov’t Auth., 8 F. Supp. 3d 9, 11 (D.D.C. 2014).

28 Id. at 12.

${ }^{29}$ See id. at $12-14$.

${ }^{30} \mathrm{Id}$. at 15 .

${ }^{31}$ Am. Fidelity Assurance Co. v. Bank of N.Y. Mellon, No. CIV-11-1284-D, 2014 WL 4471606, at*1 (W.D. Okla. Sept. 10, 2014).

32 See id.

33 Id.

${ }^{34}$ Id. at $* 1, * 2-3$.

35 Gilmore, 8 F. Supp. 3d at 15; Am. Fidelity, 2014 WL 4471606, at*1.

36 Am. Fidelity, 2014 WL 4471606, at *1, *2-3.

37 Id. at $* 2$.

${ }^{38}$ Gilmore, 8 F. Supp. 3d at 15; Am. Fidelity, 2014 WL 4471606, at*5.

${ }^{39}$ Gilmore, 8 F. Supp. 3d at 15 (stating that the defendants were "flat-out wrong that Daimler was the genesis of the [at home] rule" because that "standard was unmistakably announced in Goodyear"); Am. Fidelity, 2014 WL 4471606, at *3 (stating that "multiple 
contrary to the defendants' arguments, that Justice Sotomayor did not state in her concurrence that the "at home" rule itself was novel. ${ }^{40}$ Rather, she said that the majority's interpretation of the "at home" rule- "namely that a foreign defendant's contacts with the forum must be "viewed in comparison to the company's nationwide and worldwide activities," - -was novel and unprecedented. ${ }^{41}$ This part of the majority's holding, however, was not at issue in either of the district court cases. ${ }^{42}$

Finally, both the Gilmore and American Fidelity courts examined the lower courts' treatment of the Goodyear decision. The Gilmore court noted that more than 250 federal cases discussed the "at home" standard in the period between the Goodyear and Daimler decisions. ${ }^{43}$ Similarly, the American Fidelity court pointed out that the circuit courts have concluded that Daimler reaffirmed Goodyear's "at home" standard for general personal jurisdiction over corporations and "have not presumed general jurisdiction is lacking if the corporation's place of incorporation or principal place of business is not in the forum state." 44 The American Fidelity court also rejected the defendant's argument that pre-Goodyear Tenth Circuit precedent prevented it from raising its jurisdictional defense until after Daimler was decided because controlling circuit precedent from 2012 "clearly relie[d] upon the 'at-home' standard announced in Goodyear" and "existed... well before the Supreme Court's Daimler decision." 45 In the end, both the Gilmore and American Fidelity courts held that the defendants had forfeited their general personal jurisdiction defenses and denied their motions to dismiss for lack of personal jurisdiction.

In contrast, in Gucci America, Inc. v. Weixing Li, the Second Circuit held on similar facts that a non-party had not waived its jurisdictional defense. ${ }^{46} \mathrm{In}$ Gucci, the plaintiffs filed a lawsuit in the U.S. District Court for the Southern

statements by the Court in Daimler demonstrate that the [at home] standard ... was clearly first expressed in Goodyear").

${ }^{40}$ Gilmore, 8 F. Supp. 3d at 15 n.2; Am. Fidelity, 2014 WL 4471606, at*4.

${ }^{41}$ Gilmore, 8 F. Supp. 3d at 15 n.2 (quoting Daimler AG v. Bauman, 134 S. Ct. 746, 770 (2014)); Am. Fidelity, 2014 WL 4471606, at *4.

${ }^{4}$ See Gilmore, 8 F. Supp. 3d at 14-15 (noting that the defendants specifically argued that their contacts with the forum did not render them at home in the District of Columbia); Am. Fidelity, 2014 WL 4471606, at *4 (stating that Justice Sotomayor "was addressing a holding of the Court not relied upon by [the] Defendant").

${ }^{43}$ Gilmore, 8 F. Supp. 3d at 16.

${ }^{44} \mathrm{Am}$. Fidelity, 2014 WL 4471606, at $* 4$ (citing Sonera Holding B.V. v. Cukurova Holding, A.S., 750 F.3d 221, 222 (2d Cir. 2014); Snodgrass v. Berklee Coll. of Music, 559 F. App'x 541, 542 (7th Cir. 2014); Gilmore, 8 F. Supp. 3d at 15).

${ }^{45} \mathrm{Id}$.

${ }^{46}$ See Gucci Am., Inc. v. Weixing Li , 768 F.3d 122, 125-29, 134-36 (2d Cir. 2014); see also Laydon v. Mizuho Bank, Ltd., 2015 WL 1499185 (S.D.N.Y. Mar. 31, 2015) (finding under Gucci that a 12(b)(2) jurisdictional defense was not available before Daimler, but holding that several defendants have nonetheless waived their jurisdictional objection by waiting for seven months after Daimler was decided to raise it). 
District of New York on June 25, 2010. ${ }^{47}$ The district court issued a preliminary injunction that explicitly applied to a non-party foreign bank, and the plaintiffs served the bank with the injunction at its New York City branch in July of $2010 .{ }^{48}$ In 2011 and 2012, the district court ordered the bank to comply with the injunction and denied the bank's motions to modify the injunction and for reconsideration. ${ }^{49}$ The bank appealed. ${ }^{50}$ After oral argument in the Second Circuit, the Supreme Court decided Daimler and the bank raised the defense of lack of personal jurisdiction for the first time. ${ }^{51}$ Relying on Hawknet, Ltd. v. Overseas Shipping Agencies, the Second Circuit held that the bank was not subject to general jurisdiction in New York because its contacts were not "so continuous and systematic as to render [it] essentially at home in the forum." 52 It had "only four branch offices in the United States and only a small portion of its worldwide business is conducted in New York." 53

In reaching its decision, the Gucci court rejected the plaintiffs' argument that the bank had waived its jurisdictional defense by failing to raise it in the district court. ${ }^{54}$ The court held that the defense was unavailable in the district court because it would have been directly contrary to controlling Second Circuit precedent for the bank to argue that it was not subject to general personal jurisdiction in New York before Daimler was decided. ${ }^{55}$ The court explained in a footnote that Daimler and the Supreme Court's other general jurisdiction cases are applicable to non-parties. ${ }^{56}$ At the same time, however, the court pointed out in a different footnote that the bank was not subject to the waiver provisions in Rules $12(\mathrm{~g})$ and (h) because it was a not a "'party' that could fail to assert its personal jurisdiction defense in an answer or a motion to dismiss." 57

\section{WAIVER UNDER GOODYEAR AND DAIMLER: AN ANALYSIS}

Gilmore and American Fidelity Assurance Co. raise the intriguing question of when the Rule 12 threshold defense of lack of personal jurisdiction should be deemed "unavailable" so that failure to raise it in the first response to the complaint does not result in its waiver under Rules $12(\mathrm{~g})$ and $(\mathrm{h})$. The limited

${ }^{47}$ Gucci, 768 F.3d at 126.

${ }^{48} I d$.

${ }^{49}$ See id. at $127-28$.

50 Id. at 128 .

51 See id. at $134-35$.

52 Id. at 135 (quoting Daimler AG v. Bauman, 134 S. Ct. 746, 761 \& n.19 (2014)).

53 Gucci, 768 F.3d at 135.

54 See id. at $135,136 \&$ n. 14.

55 See id. at 135-36 (citing Wiwa v. Royal Dutch Petroleum Co., 226 F.3d 88, 93-95 (2d Cir. 2000)); Hoffritz for Cutlery, Inc. v. Amajac, Ltd., 763 F.2d 55, 57-58 (2d Cir. 1985); Dietrich v. Bauer, No. 95 Civ. 7051 (RWS), 2000 WL 1171132, at*4 n.4 (S.D.N.Y. Aug. 16, 2000)); see also supra notes 22-26 and accompanying text (discussing Hawknet, Ltd. v. Overseas Shipping Agencies).

${ }^{56}$ Gucci, 768 F.3d at 134 n.13.

${ }^{57}$ Id. at 136 n. 14 . 
circuit case law in this area suggests that this exception to Rule 12's waiver doctrine is applicable only where controlling legal authority makes it impossible to raise the defense in a pre-answer motion or answer. ${ }^{58}$ This standard itself suggests that a defense is unavailable under Rule 12 if it would violate Federal Rule of Civil Procedure 11(b)(2) for the defendant (or his attorney) to assert it. In other words, if the defense is not "warranted by existing law or by a nonfrivolous argument for extending, modifying, or reversing existing law or for establishing new law," then it is "unavailable" and not subject to waiver. ${ }^{59}$ At the same time, however, if a new rule is announced and the controlling authority is overruled or called into question, the defendant must assert his jurisdictional defense promptly or he will forfeit it.

The narrow reach of this exception is appropriate given the purpose of Rule 12 's waiver provisions, "which is the avoidance of time-consuming, piece-meal litigation of pre-trial motions." 60 Unless this exception is carefully circumscribed, defendants will frequently argue that a threshold defense was unavailable to them and therefore their failure to timely raise it should be excused. Moreover, there is no reason that a different standard should apply to a non-party once the non-party is on notice that it has become a participant in the litigation, as the bank in Gucci was once it was served with an injunction. The efficiency concerns that drive Rule 12's waiver provision apply equally to pretrial motions by non-parties.

Under the waiver standard set forth above, the defendants in Gilmore and American Fidelity and the non-party bank in Gucci waived their jurisdictional defenses by failing to assert them promptly after Goodyear was decided because there was no controlling authority that made it impossible for them to raise their jurisdictional defenses. ${ }^{61}$ Indeed, the Goodyear decision provided defendants with a legal basis to argue that general jurisdiction was lacking because they were not "at home" in the forum.

Prior to Goodyear, the law regarding general jurisdiction over corporations "was so well settled that large corporations ... did not even challenge general jurisdiction over them." 62 Thus, when the lawsuits in Gilmore and American Fidelity were filed and the bank in Gucci was served with the injunction, it was unlikely that the defendants or the bank could have raised general personal

58 See supra notes 12-28 and accompanying text.

${ }^{59}$ FED. R. CIV. P. 11(b)(2) (stating that when an attorney presents a defense to the court, he is certifying that "to the best of [his] knowledge, information, and belief, formed after an inquiry reasonable under the circumstances," that the defense is "warranted by existing law or by a nonfrivolous argument for extending, modifying, or reversing existing law or for establishing new law").

${ }^{60}$ Wright \& MilleR, supra note 6, § 1391, at 506 (quoting Tiernan v. Dunn, 295 F. Supp. 1253 (D.R.I. 1969)).

${ }^{61}$ Although Rule 12 was inapplicable to the non-party bank in Gucci, the Second Circuit appeared to apply the Rule 12 waiver standard set forth above when it held that the bank had not waived its jurisdictional defense because controlling Second Circuit precedent prevented the bank from raising it until after Daimler was decided. See Gucci, 768 F.3d at 135-36.

${ }^{62}$ Cornett \& Hoffheimer, supra note 2, at 104. 
jurisdiction as a defense. ${ }^{63}$ After Goodyear, however, the law was unclear. The Goodyear Court "articulated a new standard" and "adopted a more restrictive approach" to general jurisdiction when it announced the "at home" rule, but it did not explain how narrowly that rule should be applied. ${ }^{64}$ While the Goodyear Court indicated that a corporation is subject to general jurisdiction at its place of incorporation and principal place of business, "the opinion did not restrict general jurisdiction to those 'paradigm' places." 65 Moreover, the Court's "evaluation of the sales" in Goodyear suggested "that the Court might adopt a comparative approach under which contacts outside the state might reduce the likelihood that a corporation's in-state activity would constitute a home in the state." 66 Not surprisingly "[c]ourts and commentators reached different conclusions about whether the place where a corporation was 'at home' after Goodyear included places where it engaged in substantial activity outside its place of incorporation or principal place of business."67 Given the uncertainty in the law after Goodyear, there was no legal authority that made it futile for defendants to raise their jurisdictional arguments until after Daimler was decided.

In contrast, in Holzsager v. Valley Hospital, a case where the Second Circuit found that the defendant did not waive its jurisdictional defense under Rule 12, the personal jurisdiction doctrine at issue there had been criticized and called into question by the Supreme Court but was then reaffirmed by the Second Circuit. ${ }^{68}$ Thus, it was impossible for the defendant to raise its personal jurisdiction defense until the Supreme Court overruled the controlling Second Circuit authority in Rush v. Savchuk. ${ }^{69}$ Similarly, in Hawknet, Ltd. v. Overseas Shipping Agencies, a maritime attachment case cited by the Gucci court, the Second Circuit held that controlling precedent made it impossible for the defendant to raise its jurisdictional defense until the Second Circuit overruled that case law while the Hawknet appeal was pending. ${ }^{70}$

In American Fidelity, the defendant tried to argue that pre-Goodyear Tenth Circuit authority made it impossible to raise a jurisdictional defense until after

63 The district courts in Gilmore and American Fidelity did not identify the defendants' contacts with the forums in those cases, but it seems likely they did not have an argument against general personal jurisdiction until after Goodyear was decided. In Gucci, however, it was clear that the bank's contacts with New York subjected it to general jurisdiction there under pre-Goodyear authority, and, therefore, it would have been pointless for the bank to argue that it was not subject to general jurisdiction until after Goodyear was decided. See Gucci, 768 F.3d at 135-36.

${ }^{64}$ See Cornett \& Hoffheimer, supra note 2, at 105-06, 127.

${ }^{65} \mathrm{Id}$. at 6 . The argument that general jurisdiction over corporations should be restricted to the place of incorporation and principal place of business originated in the U.S. Chamber of Commerce's amicus brief in Goodyear. Id. at 6 n.17.

${ }^{66} I d$. at 23.

${ }^{67} \mathrm{Id}$. at $23 \mathrm{n} .60$ (citing various sources).

68 See supra notes $12-18$ and accompanying text.

${ }^{69}$ See supra notes $18-21$ and accompanying text.

${ }^{70}$ See supra notes $22-28$ and accompanying text. 
Daimler was decided. ${ }^{71}$ The district court rejected the defendant's argument, however, because controlling Tenth Circuit precedent from 2012 "clearly relie[d] upon the 'at-home' standard." 72 In contrast, in Gucci the Second Circuit held that the bank had not waived its jurisdictional defense because it would have been directly contrary to controlling Second Circuit authority for the bank to raise it pre-Daimler. ${ }^{73}$ To support this statement, the court cited three pre-Goodyear decisions from the Second Circuit that "made it clear that a foreign bank with a branch in New York" was subject to general jurisdiction there. ${ }^{74}$ In one of those cases, Hoffritz for Cutlery, Inc. v. Amajac, Ltd., the Second Circuit concluded that general jurisdiction was not available under New York's long-arm statute but did not reach the constitutional issue. ${ }^{75}$

Moreover, the Gucci court neglected to cite or discuss the import of Second Circuit cases decided in between Goodyear and Daimler that clearly recognized the "at home" standard. ${ }^{76}$ Perhaps most significantly, the Gucci court did not cite any Second Circuit cases in between Goodyear and Daimler that applied the at home standard and specifically held that a defendant or non-party with contacts similar to those of the bank in Gucci was subject to general personal jurisdiction in New York. And notably, the court did not mention Sonera Holding B.V. v. Cukurova Holding, A.S., a Second Circuit case decided only a few months before Gucci in which the court said that both Goodyear and Daimler "make clear that even a company's 'engage[ment] in a substantial, continuous, and systematic course of business' is alone insufficient to render it at home in a forum."77

Thus, despite the pre-Goodyear authority relied upon by the Second Circuit in Gucci and contrary to the Gucci court's holding, it was not impossible for the bank to raise a jurisdictional defense after Goodyear. Because the law of general jurisdiction over corporations was unclear after Goodyear and it was uncertain just how much the Court had narrowed that doctrine, a legal basis existed to argue that general jurisdiction was lacking. The bank in Gucci had four branch

${ }^{71}$ See Am. Fidelity Assurance Co. v. Bank of N.Y. Mellon, No. CIV-11-1284-D, 2014 WL 4471606, at*3 (W.D. Okla. Sept. 10, 2014).

72 Id.

${ }^{73}$ See Gucci Am., Inc. v. Weixing Li, 768 F.3d 135, 135-36 (2d Cir. 2014).

${ }^{74}$ Id. at 136 (citing Wiwa v. Royal Dutch Petroleum Co., 226 F.3d 88, 93-95 (2d Cir. 2000)); see Hoffritz for Cutlery, Inc. v. Amajac, Ltd., 763 F.2d 55, 57-58 (2d Cir. 1985); Dietrich v. Bauer, No. 95 Civ. 7051 (RWS), 2000 WL 1171132, at*4 n.4 (S.D.N.Y. Aug. 16, 2000)).

${ }^{75}$ Hoffritz, 763 F.2d at 57-58.

${ }^{76}$ See In re Terrorist Attacks on Sept. 11, 2001, 714 F.3d 659, 674 (2d. Cir. 2013) (quoting Goodyear Dunlop Tires Operations, S.A. v. Brown, 131 S. Ct. 2846, 2853-54 (2011)) (proposing that the paradigm forum for the exercise of general jurisdiction over a corporation is where it is "fairly regarded as at home"); Licci ex rel. Licci v. Lebanese Canadian Bank, SAL, 732 F.3d 161, 169 n.6 (2d Cir. 2013) (quoting the "at home" rule from Goodyear); Licci ex rel. Licci v. Lebanese Canadian Bank, SAL, 673 F.3d 50, 60 n.9 (2d Cir. 2012) (same).

${ }^{77}$ Sonera Holding B.V. v. Cukurova Holding, A.S., 750 F.3d 221, 226 (2d Cir. 2014) (quoting Daimler AG v. Bauman, 134 S. Ct. 746, 761 (2014)). 
offices in the United States and conducted only a limited amount of its business in New York. ${ }^{78}$ After Goodyear, it was at least arguable on those facts that the bank was not "at home" in New York. Put differently, if the bank had raised its 12(b)(2) jurisdictional defense under Goodyear, it would not have violated Rule 11(b)(2) because the argument that the court lacked general personal jurisdiction over it was warranted by existing law or a nonfrivolous argument for extending existing law. The defense therefore was available before Daimler was decided. ${ }^{79}$ Thus, under the Rule 12 waiver standard the bank in Gucci, like the defendants in Gilmore and American Fidelity, waived its jurisdictional argument by failing to assert it quickly after Goodyear.

\section{CONCLUSION}

Because Daimler $A G$ v. Bauman was decided over one year ago, the specific issue raised by this Response - whether a defendant who failed to raise a general personal jurisdiction defense under Goodyear can assert it under Daimler-will eventually become moot. Nevertheless, the broader question of when a threshold defense is "unavailable" under Rule 12 deserves additional scholarly attention given the dearth of case law in this area and especially in light of cases like Gucci. Instead of evaluating whether Goodyear made it possible for the bank to make a jurisdictional challenge, the Gucci court essentially held that a jurisdictional argument was unavailable because no controlling authority explicitly held that an entity like the bank was not subject to general jurisdiction until Daimler was decided. If courts take this approach to determining whether threshold defenses under Rule 12 are unavailable, defendants will be more likely to raise these defenses later in litigation and thereby seriously undermine the purpose of Rule 12's waiver doctrine.

\footnotetext{
${ }^{78}$ See supra note 57 and accompanying text.

${ }^{79}$ See FED. R. CIV. P. 11(b)(2).
} 